\title{
大きな子宮筋腫に対する安全で確実な腹腔鏡下手術を目指して
}

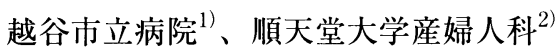

渡り 綾子 ${ }^{1)}$ 、小堀宏之 ${ }^{1)}$ 、牧野真太郎 ${ }^{11}$ 、糸賀知子 ${ }^{1)}$

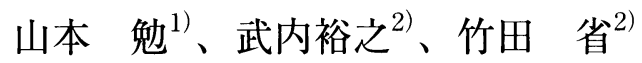

\section{Safe and Feasible Laparoscopic Myomectomy for Large Myomas}

\author{
Ayako Watari $^{1)}$, Hiroyuki Kobori ${ }^{1)}$, Shintaro Makino ${ }^{1)}$, Tomoko Itoga ${ }^{1}$, \\ Tsutomu Yamamoto ${ }^{1)}$, Hiroyuki Takeuchi ${ }^{2)}$, Satoru Takeda ${ }^{2)}$ \\ ${ }^{1)}$ Department of Obstetrics and Gynecology, Koshigaya Municipal Hospital, Saitama, Japan \\ ${ }^{2)}$ Department of Obstetrics and Gynecology, Juntendo University School of Medicine, Tokyo, Japan
}

Uterine myoma is one of the most common gynecologic benign tumors, and surgical treatment is often needed. Myomectomy is ideal for the reproductive-aged woman who desires to preserve fertility, and the laparoscopic approach is becoming increasingly popular as a minimally invasive and safe procedure. Because laparoscopic myomectomy is technically demanding, various researchers have reported criteria for the proper selection of patients for this procedure. Almost every study proposes a size of myoma as the most important exclusion criteria. In this study, we report three cases of laparoscopic myomectomies for large myomas. Precise pre-operative evaluation, GnRH analogue pretreatment, new port placement to establish a superior operative field, and pre-operative preparation of autologous blood for transfusion may enable laparoscopic myomectomy for large myomas to be a safe and feasible procedure.

【keyword】腹腔鏡下手術、筋腪核出術

\section{【緒 言】}

子宮筋腫は婦人科良性疾患の中で最も頻度が高 く、過多月経や賓血、不妊症などの原因になり得 ることより外科的治療を必要とする場合が多い。 近年の晚婚化とそれに伴う子宮筋腫好発年齢層の 妊孕性温存希望率の増加により、子宮筋腫に対す る子宮温存療法として筋腫核出術が望まれるケー スが増えてきた ${ }^{1)}$ 。更に、内視鏡手術の進歩に伴 い、腹腔鏡下子宮筋腫核出術 (laparoscopic myomectomy：以下LM）の割合が増加している が、LMは比較的難易度の高い手術術式であるこ とより、慎重な手術適応の検討が必要とされる 。 これまで多くの施設においてLM適応に関する報
告がなされているが、いずれにおいてもLM適応 の重要な制限因子として最大子宮筋腫径をあげて いる ${ }^{3-6)}$ 。当院における過去 3 年間のLM手術成績 を検討するとともに代表的 3 症例を提示し、最大 径が大きな子宮筋腫症例において安全にLMを完 遂するために行っている工夫を報告する。

\section{【対象および方法】}

対象

当施設でLMの術数・術式が比較的安定した 2005 年 1 月から 2008 年 7 月の期間におけるLM単独症 例（同時に卵巣囊腫摘出や子宮鏡手術などを行っ ていない症例）187例を対象とした。 
方法

当院に执いては手術適応と考えられる子宮筋腫 症例に対LMRI等を用いて病態を評価し、LM可 能と判断した症例に対しては原則全例術前 $\mathrm{GnRH}$ アナログ（リュープリン ${ }^{\circledR} 1.88 \mathrm{mg}$ ）を 3 〜 6 ケ月 間投与したうえで手術を施行している。

当院に扔けるトロカール穿刺部位と術者・助手 の位置関係を図 1 に示した。脆部 $(5 \mathrm{~mm})$ 、下腹 壁動静脈の外側の両下腹部 $(5 \mathrm{~mm})$ 、臍部やや上 方の左前腋窩線上（12mm）の計 4 箇所にトロカ ールを設置した。また全例気腹法を用いた。まず 気管内挿管全身麻醉下に開脚位とし腟洗浄を行い 子宮腔内にマニュピレーター（ジョンソン・エン ド・ジョンソン社）を挿入した。その後、トロカ ールを上記の通りに挿入した後、経腹的にカテラ ン針を用いて筋腫核の漿膜と筋腫被膜の間に100倍 希釈したバソプレシン (ピトレシン $\left.{ }^{\circledR}\right)$ を局注し た。針状電極のモノポーラーで筋腫核上の子宮筋 層に横切開を加え、径 $10 \mathrm{~mm}$ の腹腔鏡用ミオーム ボーラーを筋腫核に刺入、毫引し、筋腫核の摘出 を行った。筋腫核出後の子宮筋層は創部の深さに 応じて 0 号バイクリル $30 \mathrm{~cm}$ を用い $1-3$ 層に連続 縫合で閉鎖した。筋腫核は電動式モルセレーター (ジョンソン・エンド・ジョンソン社) で破砕し 体外に回収し、術後癒着防止としてセプラフィル ム ${ }^{\circledR}$ やンターシードを使用した。

大部分の症例は著者以外の同一術者（技術認定 医取得者）により施行した。

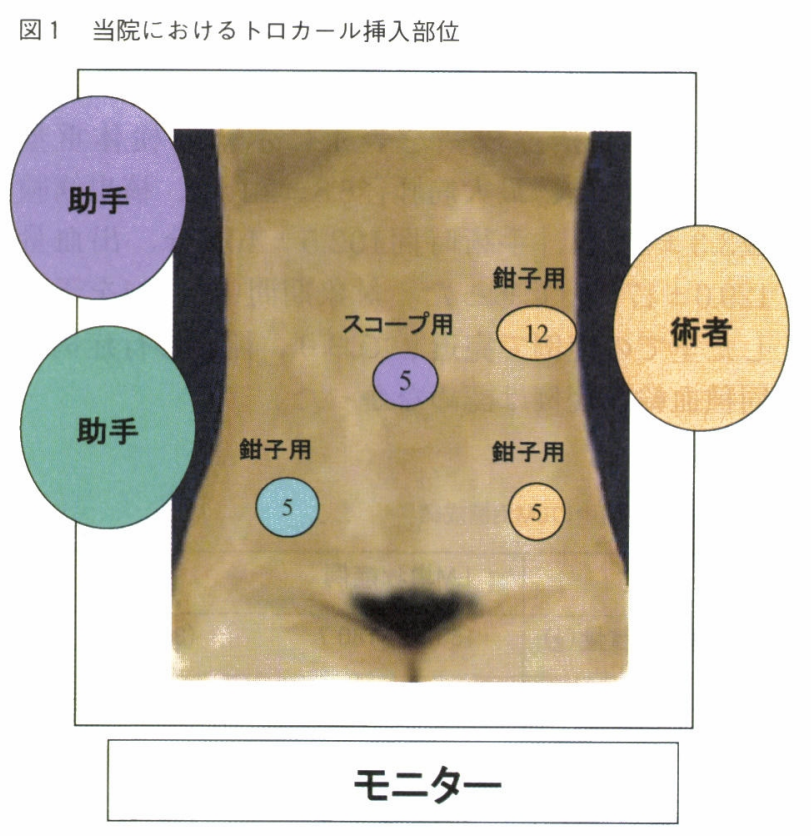

\section{【結 果】}

上述した手術方法に加え何点かの土夫を加える ことでLM完遂可能であった大きな子宮筋腫症例 のうち特徵的な 3 症例を以下に示す。

\section{症例 1 (図 2)}

31 歳 女性 1 経妊 0 経産

既往歴・家族歴：特記事項なし

現病歴：下腹部腫瘤感を主訴に近医受診し、子宮 筋腫の診断で当院紹介受診となった。初診時の MRIで長径 $12 \mathrm{~cm}$ の漿膜下筋腫 2 個認め、GnRHア ナログ 6 ケ月投与した後に再度MRIを施行した。 筋腫径の縮小は軽度にとどまったが、槳膜下筋腫 であり子宮底が臍下 $3 \mathrm{~cm}$ まで低下したためLMを 施行した。検体重量：1040g、筋腫最大径 $12 \mathrm{~cm}$ 、 核出筋腫数 7 個、手術時間 213 分、出血量 $500 \mathrm{~g}$ 。 術後経過問題なく 4 日目に退院となった。

図 2 症例 1 【31歳 1 経妊0経産】
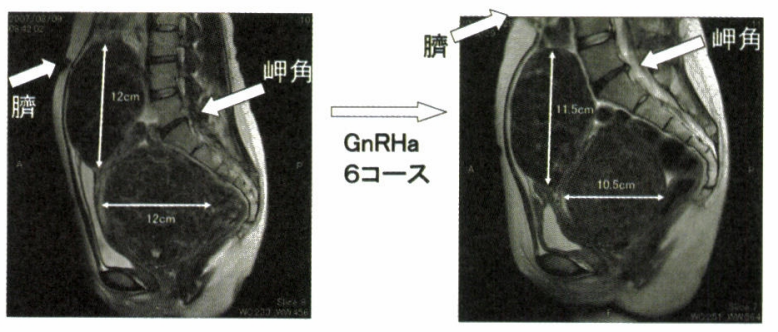

症例 2 (図 3 )

37 歳 女性 0 経妊 0 経産

既往歴・家族歴：特記事項なし

現病歴：下腹部腫瘤感を主訴に近医受診し、子宮 筋腫の診断で当院紹介受診となった。初診時の MRIで長径 $11 \mathrm{~cm} の$ 筋層内竻腫 2 個認めた。GnRH アナログを 6 ケ月投与した後に再度MRI施行した
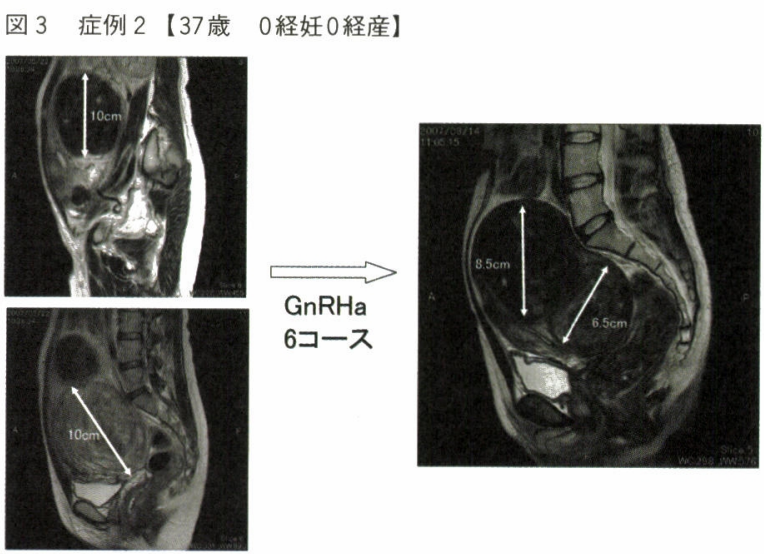
ところ、それぞれ最大径 $7 \mathrm{~cm}$ まで著明な縮小を認 めLMを施行した。検体重量：460g、筋腫最大径 $9 \mathrm{~cm}$ 、核出筋腫数 5 個、手術時間 215 分、出血量 $600 \mathrm{~g}$ (術中セルセーバー使用)。術後経過問題な く4日目に退院となった。

\section{症例 3（図 4)}

37 歳 女性 1 経妊 0 経産

既往歴・家族歴：特記事項なし

現病歴：下腹部腫瘤感を主訴に近医受診し、子宮 筋腫の診断で当院紹介受診となった。初診時の MRIで子宮後壁に $15 \mathrm{~cm}$ 大の漿膜下筋腫を認め、 $\mathrm{GnRH}$ アナログ 3 ケ月投与後に再度MRIで評価し た。筋腫径は $13 \mathrm{~cm}$ と軽度縮小を認めるのみであっ たが、ご本人のLM希望が強かったため更にGnRH アナログ 3 ケ月追加投与し、自己血䝰血を 2 回 (計 4 単位) 行ったうえで、LMを施行した。通常 通りの臍アプローチで手術を開始したが、筋腫に より視野確保困難であったため、臍上にカメラポ ートを追加設置した（図 5 )。臍アプローチ法と 臍上アプローチ法での手術視野の状態を図 6、7 に示す。検体重量：1320g、筋腫最大径 $13 \mathrm{~cm}$ 、核 出筋腫数 6 個、手術時間 215 分、出血量 $900 \mathrm{~g}$ （自

図4 症例 3【37歳 1 経妊0 経産】

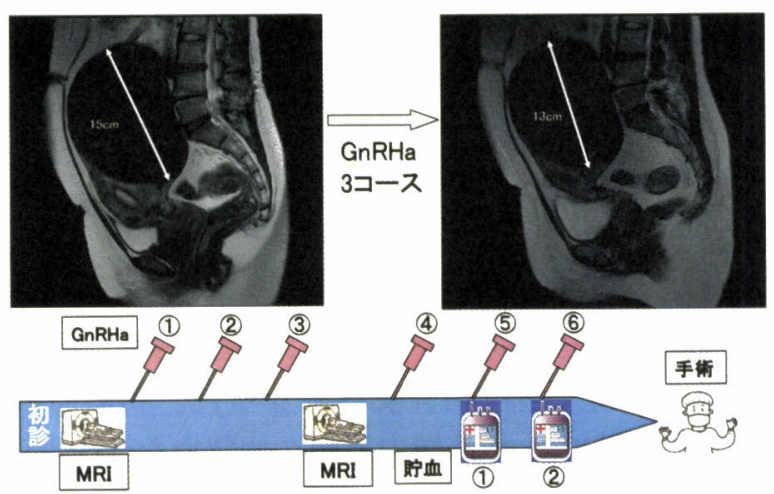

図 5 臍上トロカール挿入症例

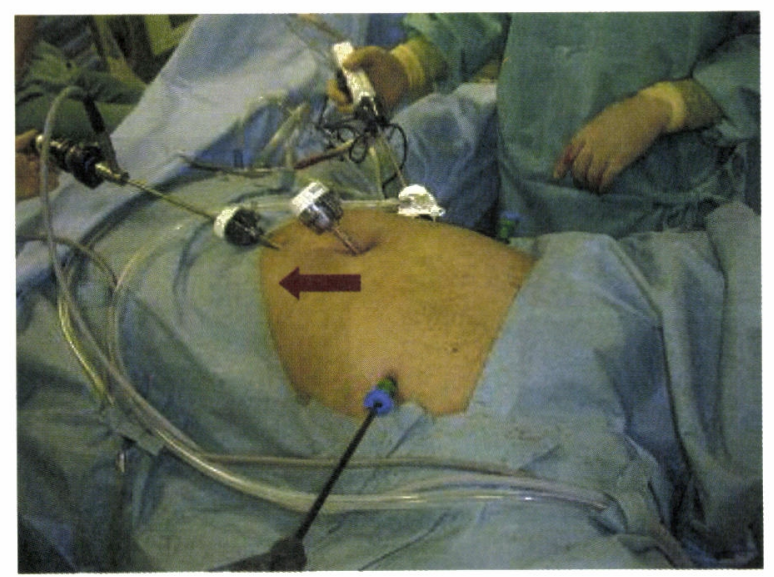

己血 4 単位使用)。術後経過問題なく 4 日目に退 院となった。

\section{図 6 臍部からの視野}

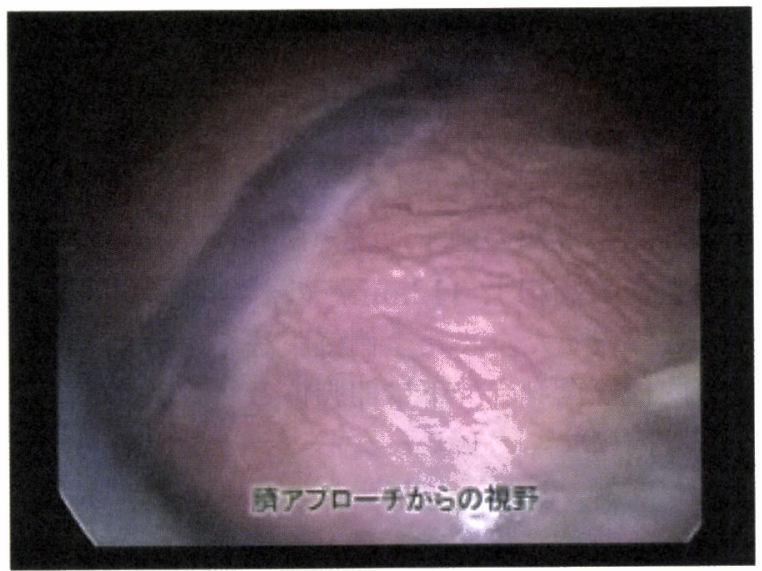

図 7 蟀上からの視野

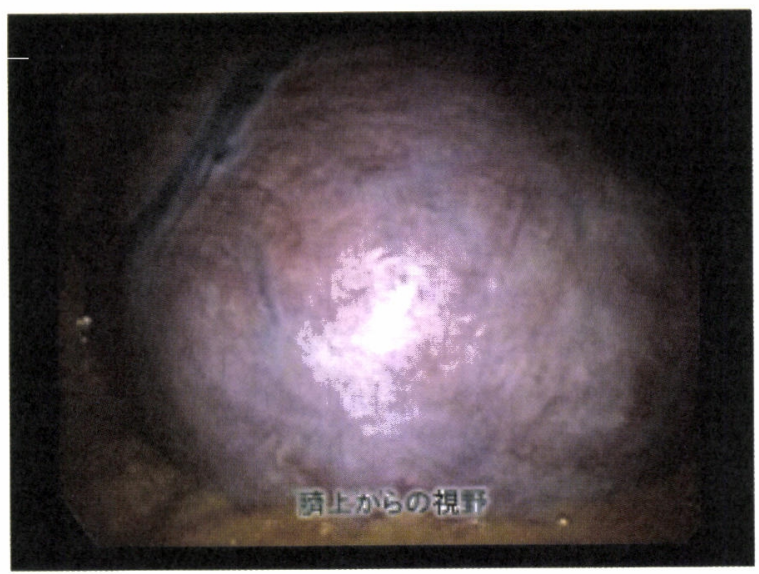

対象症例全体の平均年齢、平均身長、平均体重 はそれぞれ $35.7 \pm 4.8$ 歳、 $158.2 \pm 5.2 \mathrm{~cm} 、 55.2 \pm 8.7 \mathrm{~kg}$ であった。治療成績を表 1 に示す。検体重量 $183.1 \pm 180.7 \mathrm{~g}$ 、最大筋腫径 $6.8 \pm 2.1 \mathrm{~cm}$ 、核出筋腫 数 $3.3 \pm 3.2$ 個、手術時間 $102.5 \pm 40.8$ 分、出血量 $129.0 \pm 177.4 \mathrm{~g}$ であった。対象期間中、LMを予定 した全ての症例で完遂しており、開腹移行症例や 同種血輸血症例は認めなかった。

表 1 対象期間中のLM治療成績

\begin{tabular}{|c|cc|}
\hline & LM単独症例 & \\
\hline 平均検体重量 $(\mathrm{g})$ & $183.1 \pm 180.7$ & $(3-1320)$ \\
\hline 最大筋腫径 $(\mathrm{cm})$ & $6.8 \pm 2.1$ & $(2-15)$ \\
\hline 核出筋腫数 (個) & $3.3 \pm 3.2$ & $(1-17)$ \\
\hline 手術時間(分) & $102.5 \pm 40.8$ & $(36-253)$ \\
\hline 出血量(g) & $129.0 \pm 177.4$ & $(5-1050)$ \\
\hline
\end{tabular}




\section{【考察】}

LMは1990年頃より世界的に行われるようになっ て以降、安全に手術を行うための工夫や術式につ いて各施設で多くの検討と報告がなされている ${ }^{7-8)}$ 。 当院においてはLM基本方針として同種血輸血の 回避と 3 時間程度までの手術時間を目標として設 定している。これまでの報告より、最大筋腫径と 出血量・手術時間はいずれも正の相関関係を示す ことがわかっており ${ }^{6)}$ 、上記の目標を達成するた めには大きな筋腫症例における正確な術前評価と 慎重な症例選択、出血量、手術時間、視野のコン トロールが重要となる。最大筋腫径が大きな子宮 筋腫に対して安全な腹腔鏡手術を行うために当院 で行っている工夫を表 2 に示し以下に考察する。

\section{表 2 当院での安全な手術を行うための工夫}

\begin{tabular}{|c|c|c|}
\hline 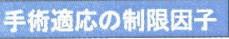 & 何前 & 街中 \\
\hline 症例の評価 & MRI等による適切な評価 & \\
\hline 筋畽の大きさ & GnRHa投与 $\Rightarrow$ 筋畽鏥小 & \\
\hline 出血量 & $\begin{array}{l}\text { GnRHa投与 } \Rightarrow \text { 血流抑制 } \\
\text { 自己血貯血の準備 }\end{array}$ & $\begin{array}{l}\text { パソプレシン局注 } \\
\text { セルセーバー準備 }\end{array}$ \\
\hline 視野確保の困䧼性 & & 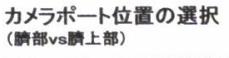 \\
\hline 手術時間 & & 手術手技全般の向上 \\
\hline
\end{tabular}

\section{(1) 正確な術前評価}

我々が最も重点をおいているものの 1 つが正 確な術前評価である。これまでLMの適応と限 界に関し諸家らが報告しているが、いずれの報 告においても術者間や施設間の均整化が困難で あることを問題点としてあげ、施設毎の検討が 必要であると結論付けている。多くの報告が筋 腫最大径や筋腫個数を適応基準としてあげてお り、また、武内らはMRIにおける子宮底の高さを LM適応基準の目安としてあげている（表 3 ） ${ }^{9)} 。$ 正確な術前評価として、内診、MRI検査などで 子宮や腹腔内の状態を評価するのは当然である が、最大径や個数だけでなく、その部位、深度 (内膜との位置関係も含め)、変性具合などに関 しても確認し腹腔内所見をイメージすることが 必要である。また、その他、手術に影響すると 思われる因子に関し見逃しが無いよう、個々の 症例に対し、開腹歴の既往、子宮内膜症の合併、 肥満の合併、主訴や自覚症状の程度などを丁寧 に評価したうえで、最終的に安全なLM施行が 可能であるかを判断している。
表 3 LM適応と限界に関する報告

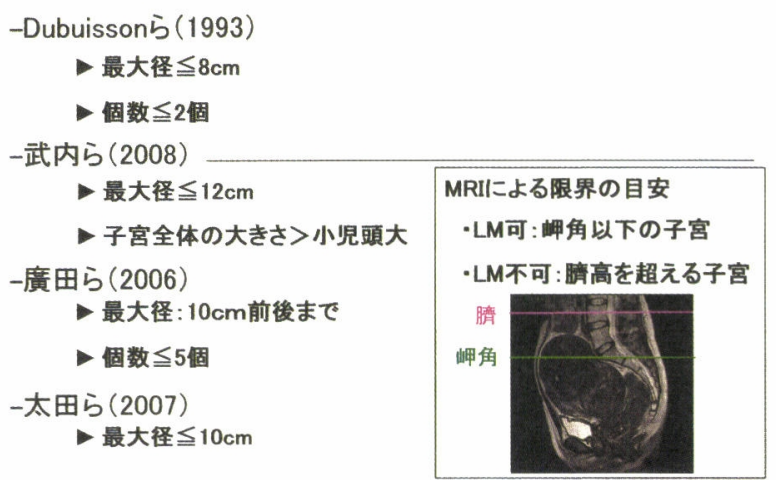

(2) GnRHアナログ投与

我々の施設では子宮筋腫径を縮小させること でLM可能サイズにするという目的と血流制限 効果により術中出血を抑える目的でLM施行症 例に対し原則全例に術前 $\mathrm{GnRH}$ アナログ投与を $3 \sim 6$ ケ月行っている。症例 2 はGnRHアナロ グ投与により著明に筋腫径が縮小した症例であ り、筋腫径縮小によりLMを安全に行うことが 可能であった。術前GnRHアナログに関しては 小筋腫核の取り残しによる再発リスクなどの観 点より否定的な意見もあるが、当施設では、視 診上や鉗子を介しての触診で筋腫部位がはっき りしない症例においてはGnRHアナログ投与前 のMRIを術中確認し目安をつけてアプローチす ることで、できる限り取り残しをしないよう心 がけている。しかしながら、早期再発の有無を 正確に評価する方法として、術後MRIの必要性 を現在検討中である。

(3) 視野確保の工夫

骨盤腔を占拠するような大きな子宮筋腫では 術中視野やハンドリングスペースの確保が困難 になる。Sinhaらは視野を確保するために大きな 子宮筋腫症例に対し筋腫を完全に核出せず子宮 に付着した状態でのdirect morcellation（挙児 希望の無い症例に対してはdevascularization併 用の上）の有用性を報告している ${ }^{10)}$ 。しかし、 子宮動脈結棌を併用できない挙児希望のある筋 層内筋腫や粘膜下筋腫症例に関しては、 morcellationをしている間の筋層切開部位から の出血が懸念される。

我々は視野確保が困難な症例に対して通常の 臍部以外に臍上カメラポートを選択することが ある。臍上カメラポートでは臍と剣状突起との 間にトロカール挿入を試みるが、同部位はLeeHuang Pointとして2001年にLeeらにより報告さ れている ${ }^{11)}$ 。彼らは開腹既往例や婦人科悪性腫 
瘍症例に対するファーストアプローチの場所と して剣状突起と臍の中間部からのアプローチを 腹腔内癒着による臓器損傷などを回避する方法 として推奨している。我々の場合は、まず臍か らファーストアプローチを行い、そこから上腹 部を観察した状態で肝鎌状間膜なども確認しつ つ臍上トロカールを挿入している。症例 3 にお いては臍上ポートを用いたことにより視野が格 段に改善し手術継続が可能であった。Leeらが 強調した安全性という観点以外に、視野の確保 という観点からも同部位からの操作は推奨でき るものと思われる。また、当院においてはカメ ラポートとして $5 \mathrm{~mm}$ 径の小さなトロカールを用 いているため比較的ポートの移動が容易である とも考えられる。

(4) 自己血貯血・セルセーバーの準備

出血が多くなることが予想される症例に関し ては自己血貯血を準備し、自己血貯血の準備が 不可能であった症例に関しては術中セルセーバ 一の準備を行うことが重要であると考えられる。 しかし、コスト面や患者の負担を考慮すると、 その準備はある程度ハイリスクの症例に限られ るべきである。当院の手術成績を振り返ると、 確かに最大筋腫径と出血量は相関関係にあるが、 $600 \mathrm{ml}$ を超えるような出血は、最大筋腫径が $10 \mathrm{~cm}$ 以上でかつ勒帯内発育であったり、筋腫と 正常筋層の境界が不明瞭である変性筋腫であっ たりなど特殊症例に限って認める傾向があった。 よって、積極的に自己血貯血の準備をすすめる ひとつの目安として、最大筋腫径が大きく、か つ発生部位が特殊であったり強い変性が疑われ たりする症例が挙げられると思われる。

また、自己血貯血を準備していることによっ て、術者としても積極的に手術に取り組むこと が可能である。症例 3 においては $13 \mathrm{~cm}$ の漿膜下 筋腫以外に径 $7 \mathrm{~cm}$ の勒帯内発育筋腫を含めた計 6 個の筋腫核出が可能であったが、自己血貯血 を準備していたことで、出血量により手術中断 することなく、取り残しのないよう手術を進行 できたと思われる。

これまでLM適応に関しては各施設より報告さ れているが、いずれも各々の施設や術者毎の適応 の検討が必要と結論付けている。前述したとおり 当院におけるLM基本方針は同種血輸血の回避と 3 時間程度までの手術時間であるが、その目安と して適応基準を最大筋腫核 $12 \mathrm{~cm}$ 以内（ただし、槳
膜下筋腫に関してはこの範疇にない)、筋腫核数 10 個以下と設定している。しかし、実際にはこれら はあくまで目安であり、安全で確実な手術を達成 するためには個々の症例の評価を如何に正確に術 前に行えるかが重要になってくると思われる。今 回我々は、比較的大きな子宮筋腫LM症例を提示 し、当院で術前から術中にかけて行っている様々 な工夫を紹介した。これらを用いることにより、 従来よりも安全に手術を行うことが可能であると 思われるが、今後も、出血量の削減や手術時間の 短縮を達成するための更なる取り組みが必要と考 えている。

本論文の要旨は第48回日本産科婦人科内視鏡学 会において発表した。

\section{参考文献}

1) Alessandri F, et al.: Randomized study of laparoscopic versus minilaparotomic myomectomy for uterine myomas. J Minim Invasive Gynecol. 2006; 13: 92-97.

2 ) Agdi M, Tulandi T.: Endoscopic management of uterine fibroids. Best Pract Res Clin Obstet Gynaecol. 2008; 22: 707-716.

3 ) Dubuisson JB, et al.: Laparoscopic myomectomy. Gynecol Endosc. 1993; 2: 171-173.

4 ) Takeuchi H, Kuwatsuru R.: The indications, surgical techniques, and limitations of laparoscopic myomectomy. JSLS 2003; 7: 89-95.

5 ) 廣田穣、宇田川康博 : 腹腔鏡下筋腫核出術の適応と限 界、産婦人科治療、2006; 92: 271-275.

6 ）太田邦明、他：東邦大学内視鏡チームにおける腹腔鏡 下子宮筋腫核出術の後方視的検討、日産婦内視鏡会 誌、2007; 23: 181-185.

7 ) Takeuchi H, et al: A new enucleation method for cervical myoma via laparoscopy. J Minim Invasive Gynecol. 2006; 13: 334-336.

8 ) Damiani A, et al.: Laparoscopic myomectomy for very large myoma using an isobaric (gasless) technique. JSLS. 2005; 9: 434-438.

9 ) 武内裕之: 順天堂大学産婦人科内視鏡チームによる腹 腔鏡手術マニュアル、2008; 中外医学社.

10) Sinha R, et al.: Laparoscopic Myomectomy: Do size, Number, and Location of the Myomas Form Limiting Factors for Laparoscopic Myomectomy? J Minim Invasive Gynecol. 2008; 15: 292-300.

11) Lee CL, et al.: A new portal for gynecologic laparoscopy. J am Assoc Gynecol Laparosc. 2001; 8: 147-150. 